\title{
Why Do Adults Use Baby Talk in the Online Space? \\ Baby Talk as a Pragmatic Face Device in Adult Communication
}

Yetişkinler Çevrimiçi Sosyal Ağlarda Neden Bebek Gibi Konuşur?

Edimsel bir Yüz Aracı Olarak Bebek Konuşması

\author{
Esranur Efeoğlu-Özcan \\ Gazi University \& Middle East Technical University, Turkey \\ Yasemin Erdoğan-Öztürk \\ Karabük University \& Middle East Technical University, Turkey \\ Hale Işık-Güler \\ Middle East Technical University, Turkey
}

\begin{abstract}
This study aims to explore the motives and pragmatic functions of baby talk in adultto-adult communication in the online space. By concentrating on a recent communicative trend of using scripted baby talk in Turkish language by the Turkish social media users, we seek to answer why adults collectively adopt a speech register which is primarily used in adult-infant communication in their online socializations. Drawing on the Goffmanian notion of face and the theory of (im)politeness, the study argues that baby talk among adults in the online space functions as a powerful multidirectional and multifunctional face device addressing the notion of face in diverse directions and communicative goals. The most significant pragmatic functions of adult baby talk are found to be attacking/threatening one's face, responding to face attacks and lastly enhancing/boosting one's face. Face attacks were observed to occur through imposing sarcasm, mock-politeness, verbal aggression and insult while face boosting communicates affection, admiration and love. We also suggest that new affordances of the online space lead to the transformation of baby talk as a register among adults and its recontextualization as a tool for a new way of online language socialization.
\end{abstract}

Keywords: Baby talk, face, online space, adult-to-adult communication, online socialization

Öz

$\mathrm{Bu}$ çalışma, çevrimiçi sosyal ağlarda yetişkinler arası iletişimde bebek konuşmasının edimsel işlevlerini ve motivasyonlarını araştırmayı amaçlamaktadır. Yeni bir çevrimiçi iletişim eğilimi olarak Türkçe bebek konuşmasının yazılı versiyonlarının Türk sosyal medya kullanıcıları tarafından kullanımına odaklanarak, yetişkinlerin çevrimiçi sosyalleşmelerinde öncelikli olarak yetişkin-bebek iletişiminde kullanılan bir dil değişkesini neden kolektif bir biçimde kullandıkları sorusunu yanıtlamaya çalışıyoruz. Çalışma, yüz kavramına ve incelik/kabalık kuramına dayanarak, çevrimiçi alanda yetişkinler arasında bebek konuşmasının çok yönlü, çok işlevli bir yüz aygıtı olarak işlev gördüğünü ve yüz kavramını farklı doğrultularda ve farklı iletişimsel amaçlarla ele aldığını savunuyor. Çalışmada, yetişkin bebek konuşmasının en önemli edimsel işlevlerinin kişinin yüzüne saldırma/ yüzü tehdit etme, yüz saldırılarına yanıt verme ve son olarak kişinin yüzünü güçlendirme/güçlendirme olduğu bulunmuştur. Yüz

CUJHSS, December 2021; 15/2: 311-329.

(C) Çankaya University ISSN 1309-6761 Printed in Ankara

Submitted: August 20, 2021; Accepted: October 20, 2021

ORCID\#: 0000-0001-9627-4628, 0000-0001-5033-0436, 0000-0002-6859-9377

hisik@metu.edu.tr 
tehditlerinin alaycılık, sahte-incelik, sözlü saldırganlık ve hakaret yoluyla gerçekleştiği gözlemlenirken, yüz güçlendirmenin sevgi, hayranlık ve sevgiyi ifade ettiği gözlemlenmiştir. Son olarak, çevrimiçi alanın yeni olanaklarının, yetişkinler arasında bir değişke olarak bebek konuşmasının dönüşümüne ve yeni bir çevrimiçi dil sosyalleşmesinin aracı olarak yeniden bağlamsallaştırılmasına yol açtığını öneriyoruz. Anahtar Kelimeler: Bebek Konuşması, yüz, çevrimiçi sosyal ağ, yetişkinler-arası iletişim, çevrimiçi sosyalleşme

\section{Introduction}

Baby talk refers to a "simplified speech register with special lexical items, morphemes, words and constructions modified from adult speech" (Caporael 876). This melodious and high-pitched register is used by adults to "simplify, clarify and add affect" to language in adults' communication with infants or small children (Caporael et al. 746). Although this unique yet universallyobserved communicative phenomenon is considered appropriate only between adults and infants with respect to the pragmatic norms surrounding adult-toadult interaction, we are aware of its presence among adults in different contexts, which is called secondary or displaced baby talk (Ferguson 219). However, despite our personal and observational familiarity with the communicative practice of secondary baby talk, the question of why adults use baby talk to communicate other adults is very rarely addressed so far except few major contributions in the field of psychology, assessing the perceptions/attitudes towards baby talk between adults (see Caporael 876; Caporael at al. 746; Bombar and Littig 137).

Baby talk in adult communication is reported to be interpreted as 'normal' or appropriate only when it occurs between caregivers and the elderly (Caporael 876), romantic partners (Bombar and Littig 137) and close friends to communicate affection, attention and emotional bonding. However, we recently witness in the Turkish context that baby talk is frequently performed in the online space by the social media users in its written form on an everyday basis. Since baby talking in the Turkish language involves consonant replacements and shifts to a great extent besides its paralinguistic features, its scripted manifestations become easily distinguishable in the online space. This recontextualization of secondary baby talk among adults in the online sphere adds to the complexity of baby talk and positions it within a one-of-a-kind context.

In this respect, our study focuses on this under-studied and highly-neglected phenomenon, namely, baby talk in adult-to-adult communication. We seek to gain insight into our observational awareness concerning the use of baby talk directed at adults in the online space by exploring its occurrence and functions in an empirically systematic analysis. Our study investigates why baby talk is used on Twitter to address other adults and aims to document its pragmatic and social functions in online interactions.

Drawing on the theories of face (Goffman 213) and (im)politeness (Culpeper, Impoliteness 20; "Politeness and impoliteness" 391), we primarily argue that 
baby talk in adult-to-adult communication indexes a central function of addressing face in various ways. Our study reframes baby talk as a multidirectional and multifunctional face device in social interaction, navigating between the extreme ends of the face spectrum ranging from boosting to explicitly attacking someone's face as well as other functions in the middleground such as responding to face attacks, mitigating them and saving the face of one's own or others. In this sense, our empirical evidence suggests that baby talk operates as a powerful tool to (i) boost face through communicating affection, love and positive feelings; (ii) attack face through communicating negative and offensive attitudes, feelings, behaviours towards others such as sarcasm, insult and invalidation; (iii) manage face-work (Goffman 213) to respond to face threatening acts.

We aim to introduce baby talk as a recontextualized communicative phenomenon leading to a new type of language socialization practice in the online space, which infringes the norms considered appropriate in face-to-face interactions and initiate new forms of online socializations. Given that no other research study empirically explored how baby talk in adult-to-adult communication relates to face within the field of linguistics, our study might significantly contribute to the literatures of baby-talk, language socialization and pragmatics and online communication since it is the very first attempt to analyse baby-talk practices between adults as a socio-pragmatic phenomenon with empirical data.

\section{Baby Talk: An Overview}

\section{Defining baby talk as a speech register}

Baby talk, also called infant-directed speech (IDS), child-directed speech (CDS) or motherese, is defined as a simplified speech register with a set of distinctive characteristics, used by adults to address infants and young children between the ages of 2-5 (Caporael 876; Ferguson, "Baby Talk in Six Languages" 103, "Baby Talk as a Simplified Register" 219). Although the name might imply otherwise, it is the adults who initiate and sustain baby talk (Ferguson, "Baby Talk in Six Languages" 103; Kelkar 40). Baby talk, in this sense, refers to a distinct speech system in which adults modify their way of speaking when they talk to small children and which is mostly considered as "not normal" when communicating with other adults (Ferguson, "Baby Talk in Six Languages" 103). The existing research studies on baby talk generally focus on this primary context concerning language acquisition, involving the interactions between adults and babies/small children as the main interlocutors.

Ethnographic research records suggest that baby talk is universally observed across all languages and mostly show linguistic commonalities as well as some variation (Ferguson, "Baby Talk in Six Languages" 103, "Baby Talk as a Simplified Register" 219). It was assumed in the earliest studies that baby talk "exists in all societies as a stable conventionalized register... and is necessary for children's language acquisition" (Solomon 125). In these early seminal studies, a number of distinctive characteristics marking the phenomenon of baby talk 
are listed. Such characteristics allow us to intuitively identify baby talk when we hear it (Caporael et al. 746). These distinguishing linguistic features include prosody (i.e. high pitch, distinct exaggerated intonation, overenunciation, slower rate); distinct vocabulary and lexicon (i.e. invented words, kin terms, terms of endearment and diminutives, onomatopoeic words); syntax and grammar (i.e. shorter and simpler sentences, repetition, greater use of nouns rather than pronouns or verbs); phonology (i.e. reduplication, cluster reduction, special sounds, sound replacement) and discourse (i.e. questions, shifts in pronouns) (Ferguson, "Baby Talk as a Simplified Register" 219; Bombar and Littig 137; Solomon 121).

Apart from its formal features as listed above, baby talk has a number of critical communicative functions in adult-baby communication. Although it was seen as a crucial practice for infants' language acquisition from very early on, baby talk is observed to occur in a range of circumstances where language acquisition is not the primary concern (Bombar and Littig 137). Ferguson ("Baby Talk in Six Languages" 103) proposes that baby talk reflects "a desire on the part of the user to evoke some aspect of nurturant-baby situation" on the side of the baby (e.g. to get attention) and on the side of the nurturant (e.g. to show affection and protectiveness with a sense of pleasure). In this respect, baby talk has been described by Ferguson ("Baby Talk as a Simplified Register" 219) to perform three main functions in adult-infant communication, which are simplification, clarification and adding affection to language (as cited in Caporael et al. 746).

\section{Baby talk in adult-to-adult communication}

As mentioned in the previous section, baby talk is observed in a variety of communicative and social circumstances besides language acquisition. In a similar vein, baby talk is not directed only to infants and young children. Although baby talk has been most extensively investigated as it is used by adults (mostly mothers) to infants, even the earliest studies anecdotally stated that baby talk is performed in other contexts and directed to other adults. This is called secondary baby talk (Caporael et.al 750; Bombar and Littig 137). The conceptualizations of secondary baby talk argue that baby talk carries a potentially significant communicative function in adult-to-adult interaction. However, the argument that baby talk has a secondary use in adults' everyday lives has been mainly based on occasional observations and anecdotal reports rather than empirical evidence. Secondary baby talk, in this sense, has been rarely studied and is greatly in need of systematic investigation with empirical data.

In his seminal article Baby Talk in Six Languages, Ferguson ("Baby Talk as a Simplified Register" 219) very briefly notes that baby talk, in addition to its primary use, is also used "to talk to pets and between adults in situations with 'baby' aspects". Exploring Marathi baby talk, Kelkar also lists three types of situations where adults resort to baby talk: "(a) talking to a child as a sort of fond concession to the child's imperfections" as the primary function of baby talk; "(b) talking to infants or pet animals, largely for his own pleasure and within the family circle" as tool of affection and pleasure; and lastly "(c) talking to another 
adult when wishing to reproduce child speech or when wishing to 'baby' or to be 'babied' by the latter" (41). Those situations with baby aspects point to social roles of the participants. Solomon (122) summarizes that baby talk is talked to other adult interlocutors including "the elderly, the intellectually disabled, lovers, foreigners, family pets, and even plants" by highlighting the existence of various types of interlocutors in secondary baby talk.

The question of why adults with full language competence and repertoires prefer baby talk among themselves has similarly been reflected mostly on an intuition, observational and anecdotal account with little empirical evidence, particularly in the early discussions. Given the implications of a babylike status for the addressee and the addresser as expressed in the quotes above, baby talk might offer rich, multi-layered and complex potentials in adult communication. Baby talk is most often observed between lovers, close friends or the caregiversthe elderly, which suggests that it operates to communicate affection, intimacy, closeness and nurturance (Caporael, 1981; Caporael et al. 1983). However, it was also anecdotally reported that baby talk presents possibilities to communicate a derogatory message signalling the addressee's powerlessness and childlike/babylike status (Ferguson, "Baby Talk as a Simplified Register" 219). It was pointed as a potential device to manifest irony, humour, insult and political wit (Caporael et al. 746). Similarly, Kess and Kess (201) put forward in their observational note that baby talk among adults only emerges in "marked situations like sarcasm, satire, or poignant speech".

The existing empirical studies with a systematic approach to adult baby talk are very few in number and concentrate on the phenomenon of baby talk (i) between caregivers and institutionalized elderly (Caporael 876; Caporael et al. 746) and (ii) between romantic partners (Bombar and Littig 137; Kranjčić 3). These studies mainly explored how baby talk is perceived by listeners. In her field study in a nursing home, Caporael (876) found that baby talk used by the caregivers, directed to the institutionalized elderly in the nursing home was a common and significant practice in the language environment of the elderly. The judgement tests implemented to psychology undergraduate students revealed that baby talk to the institutionalized elderly is perceived as a positive speech register conveying affection by the outside listeners. However, in a later study, Caporael et.al (746) rated the judgements of the elderly and their caregivers towards baby talk. In contrast to the previous study, the results revealed that institutionalized elderly who are cognitively and physically functioning at a higher rate did not like/prefer to be addressed via baby talk speech by their caregivers. In contrast, the lower-functioning elderly tended to perceive baby talk more positively. The authors rightly point out that evaluation of baby talk communicating either a pejorative or nurturant affect depend on "the ear of the target, not just any listener (Caporael et al. 752). This discussion explains well why college students and the elderly contrastively rated baby talk to the institutionalized aged.

In the second line of research, Bombar and Littig (137) argued in their questionnaire-based study that baby talk is frequently observed in adult 
romances and friendships. It functions to express an intimate psychological connection, secure attachment, affection and play. The participants perceived baby talk as an acceptable register within the romantic, intimate relationships despite their strong concerns about the social acceptability of baby talk. They also reported using baby talk to express affection and good feelings as well as to prompt or claim similar expressions from their partners. In a much recent crosscultural study investigating the perceptions of English and Crotian native speakers on adult-to-adult baby talk, Kranjčić (17) proposed that the social attitudes towards baby talk to children and baby talk to other adults significantly differ. Baby talking in romantic relationships, close friendships and parental relationships were considered acceptable and a sign of intimacy.

The studies briefly discussed here primarily foreground the nurturant role of baby talk communicating affection and attention. However, there is no empirical study elaborating on how baby talk is used in communication at an interactional and discursive level, with regard to the possibilities of baby talk as a means of conveying criticism, sarcasm, irony or insult despite the existence of such assumptions based on casual observations. In this sense, our study intends to make a significant contribution to the adult-to-adult baby talk research in the field of pragmatics by providing systematic evidence to complex sociopragmatic functions of baby talk in Turkish language.

\section{Methodology}

This study utilizes a corpus-assisted discourse approach (CADS) (Partington, "Corpora and Discourse"11; "Evaluating Evaluation" 261) in order to explore the phenomenon of baby talk in online Turkish discourse. By combining both quantitative and qualitative perspectives, CADS emphasizes an eclectic approach to uncover the non-obvious meaning (Partington et al., "Patterns and Meanings" 11) in discourse and makes frequent use of corpus-external data to explore the phenomenon in question. CADS typically makes use of specialized corpora to investigate dynamic and emergent nature of meaning and interpret patterns of both form and function based on the interactional contexts. In this line, this study approaches the data from a corpus-assisted discourse perspective in the sense that firstly a specialized corpus of online Turkish baby talk was compiled and the structure of the phenomenon was explored through the query run by the keyword çen (second person singular pronoun, scripted in baby talk) in the corpus. Later, an analysis focusing on face-work was carried out to explore the patterns of çen identified via corpus tools. The interactional functions of baby talk were interpreted within the frameworks of face (Goffman, 213) and (im)politeness (Culpeper, Impoliteness 20; "Politeness and impoliteness" 391) in detail.

\section{Sampling and data collection}

Based on the relevant literature on the linguistic properties of baby talk, a list of potential keywords (baby talk variants of pronouns and verbs in Turkish) were generated by the researchers and a pilot study was performed to identify the keyword/keywords which are salient in baby talk in online discourses. As the 
most distinguishable characteristics of baby talk, keyword çen (baby talk variant of Turkish pronoun 'sen' which is produced by replacing the consonant ' $s$ ' with 'ç') was identified as a trigger for the manifestation of baby talk in the data. Turkish has two forms of 2nd person pronouns, namely 'siz' (V form) and 'sen' ( $\mathrm{T}$ form). The choice of sen/siz is determined based on several factors such as age, social status, formality/solidarity and group membership (König 175; Balpinar 288). The 2nd person singular pronoun 'sen' in Turkish acts as a pronominal address term which is coded as an 'intimate and close relationship marker' in Turkish and used to convey sympathy and love (Bayyurt 25). The adult-to-infant interactions in baby talk also make use of similar shifts in pronouns (Ferguson, "Baby Talk as a Simplified Register" 219; Bombar and Littig 137; Solomon 121). In the case of Turkish, it is the variant of 2nd person pronoun 'sen' that acts as a relationship indexing marker and phatic interjection in baby talk.

The data used in this study were collected from Twitter using the data import function of the software MAXQDA2020. Tweets were imported based on the inclusion criteria that the they (i) are in Turkish language and (ii) contain the keyword çen. Based on these parameters, the software imported 10,000 tweets in batches of 1,000 posted by Twitter users within the timespan of a week (29.03-04.04.2021). As the phenomenon in question is not confined to a specific time period or group of people, the researchers focused on the first batch of the imported data which corresponds to a thousand tweets posted from March 29th to April 1st, 2021.

The tweets in the first batch have been transferred to Excel spreadsheets and all of the tweets were manually checked in order to eliminate the instances of çen which are not within the scope of investigation. This manual check was based on the two-step exclusion criteria designed by the researchers. In the first step, the instances of çen in which çen was a part of (i) proper names (i.e., names, surnames, and Twitter handles), (ii) lexical items with semantically different meanings in Turkish (i.e., çene, çen çen, geçen), (iii) lexical items from other languages (i.e., Kurdish, Korean), and (iv) unclear utterances were excluded $(n=452)$ from the data set. In the second step, tweets which do not provide sufficient context were excluded from the study $(n=201)$ based on the criteria that (i) the account is suspended/protected, (ii) tweet is deleted after the data collection, and (iii) topic is unclear. The two-step exclusion criteria yielded 347 tweets in total and each tweet was assigned a unique ID. Concerning the intertextuality frequently observed in digital discourse; the embedded visuals, videos, gifs, and hyperlinks to other web sites were also coded and compiled as complementary sources of context for the interpretation of the data.

\section{Data Analysis}

First of all, the profile of çen in the data was described in terms of the frequency of occurrence, sentence structures, its positions in sentences and the identified accompanying tokens of çen in the sub-corpus. After the descriptive observations, an initial coding of the topics, communicative goals of tweets and the entities denoted by pronoun çen was conducted by the researchers. Later, a 
second phase of coding with regard to functions of çen within the framework of face and (im)politeness was completed.

Given that this study investigates the pragmatic functions of baby talk which has an inherent 'face boosting' function as it is an affect-oriented speech (Bombar and Littig 137), when a mismatch between an affect-oriented form and pragmatic function other than affection is observed, there could be potential cases of face attacks. For the purposes of exploring the functions of baby talk other than face boosting, this study employed Culpeper's ("Towards an Anatomy of Impoliteness" 349; Impoliteness 20; "Politeness and impoliteness" 391) analytic frame for (im)politeness. In this frame, Culpeper builds up on the Goffmanian concept of face which is defined as the positive social value the positive social value a person effectively claims for himself by the line others assume he has taken during a particular contact' (Goffman 5) and argues that impoliteness occurs when (1) a speaker communicates a face-attack intentionally, (2) hearer perceives the behavior as intentionally face-attacking, or a combination of (1) and (2) (Culpeper et al. 1545; Culpeper Impoliteness 50). To elaborate; Culpeper, Bousfield and Wichmann (1545) mapped out the response options to manage face attacks. When a speaker perceives an impoliteness act, namely a face threatening act (FTA), they have the options of either to respond or stay silent. The speakers who choose to respond can either accept the face attack or they can counter it. Countering the face attack also has two different patterns, namely offensive or defensive strategies. It is important to note that there are also instances where incompatible polite and impolite moves are observed in the same utterance, which is called mock-politeness (Taylor, "Women are Bitchy but Men are Sarcastic?" 415).

Within the scope of facework, the tweets which utilizes çen for denoting humans $(n=304)$ were coded for their pragmatic functions of (i) face-boosting, (ii) imposing face-attacks, and (ii) responding to face-attacks. In accordance with Culpeper, Bousfield and Wichmann's (1545) model, responses to face threats were also elaborated.

\section{Findings}

The data presented in this study is a sub-corpus which belongs to a larger corpus of 194,941-token corpus of Turkish online baby talk. The frequency analysis shows that çen occurs 462 times in the 3,574-token sub-corpus which consists of 347 tweets. In this section, the descriptive observations regarding the structure of baby talk triggered by çen will be presented. It will be followed by a discussion the pragmatic functions of baby talk based on the notion of face.

\section{Descriptive observations}

The initial analysis shows that linguistic features of adult-to-adult baby talk triggered by lexical item çen in online Turkish discourse bear several distinctive characteristics, similar to the phenomenon of adult-to-infant baby talk outlined previously by the literature such as lexicon (i.e., the use of endearments and diminutives), syntax (i.e., shorter and simpler sentences and repetition), phonological representations (i.e., sound replacement) and discourse (i.e., using 
questions and shifts in pronouns) (Ferguson, "Baby Talk as a Simplified Register" 219; Bombar and Littig 137; Solomon 121). In addition to the structural observations indicated by the literature, this study adds to the existing research in terms of providing a detailed account of pragmatic functions of the adult-to-adult baby talk. In order to describe the phenomenon in question with regard to its distinctive characteristics in line with the literature as well as its diverging features, the frequency of occurrences of çen and its sentence positions; the distributions of topics; communicative goals achieved through baby talk; and entities denoted by pronoun çen will be presented in this section.

The frequency analysis shows that çen occurs 462 times in the 3,574-token subcorpus which consists of 347 tweets. Categorized with regard to functionality of sentence types in Turkish, the majority of çen instances appear in interrogative form (95\%) while there are also instances of çen used in declaratives $(\mathrm{n}=10)$, along with imperative and exclamatory ( $\mathrm{n}=5$ each) forms. The structure of a typical interrogative sentence is as follows:

\section{Original Tweet: $\quad$ çen aşı mı oldun yaa!? Gloss: English Translation: 'aww did you fall in love?'}

As observed in the example above, the second person singular form of pronoun you in Turkish undergoes a sound placement in which consonant ' $s$ ' is replaced with consonant ' $c$ '. Furthermore, the interjection 'yaa', which emphasizes the feeling expressed by the speaker accompanies çen, appears to be the most frequently observed collocate of çen in the corpus (MI2, L5-R5, C6-NC5, no filter applied). In terms of the position of çen in the sentences, it appears most frequently in the initial position ( $\mathrm{n}=183)$, followed by the final position $(\mathrm{n}=83)$, and lastly the medial position $(\mathrm{n}=28)$. Additionally, through the repetition of çen both at the beginning and at the end of the sentences, çen frequently undergoes the act of reduplication in the baby talk $(\mathrm{n}=84)$. It is important to note that çen has various accompanying linguistic devices in each position such as the interjection 'yaa' in the sentence initial position as exemplified in (a). Accompanying tokens are not limited to interjections. Our analysis shows that emoticons which display various pragmatic functions in digitally-mediated forms of discourse are also frequently utilized by the Twitter users who perform baby talk. For example, the tweet in the example (a) has the communicative goal of expressing affection to the addressee and the emoticon 'smiling face with heart-eyes' manifested in the final position following çen is used strengthen the tone of affection (Yus 511; Lüdtke 211). The distribution of çen in different sentence positions and additional patterns in each position are presented in Table 1 below.

Table 1. Sentence positions of çen in the sub-corpus of baby talk

\begin{tabular}{l|l|c}
\hline $\begin{array}{l}\text { Sentence } \\
\text { position }\end{array}$ & Accompanying tokens & No of occurences \\
\hline Initial & $\begin{array}{l}\text { username/name + çen } \\
\text { ay/ayy/ayuyy }+ \text { çen }\end{array}$ & \\
\hline
\end{tabular}




\begin{tabular}{|c|c|c|}
\hline & $\begin{array}{l}\text { ya/yaa/yiaaa/yaağğ + çen } \\
\text { oy/oyy/oyş + çen } \\
\text { ama + çen } \\
\text { hani + çen } \\
\text { anamm + çen } \\
\text { random laugh }{ }^{1}+\text { çen }\end{array}$ & 183 \\
\hline Medial & $\begin{array}{l}\text { çen } \\
\text { çeni }\end{array}$ & 28 \\
\hline Final & $\begin{array}{l}\text { çen + emoticon } \\
\text { çen + oyyy } \\
\text { çen + hee } \\
\text { çen + yaaa } \\
\text { çen + trololol/aguguk } \\
\text { çen + random laugh }\end{array}$ & 83 \\
\hline Reduplication & çen + utterance + çen & $\begin{array}{c}84 \text { (no of } \\
\text { tokens=168) }\end{array}$ \\
\hline \multicolumn{2}{|c|}{$\begin{array}{r}\text { Total } \\
\end{array}$} & 462 \\
\hline
\end{tabular}

In terms of the entities çen denotes or refers to, while the majority of them are used to address Twitter users ( $\mathrm{n}=154,33 \%$ of the sample), the rest of the entities show a wide range of variety. The sub-corpus demonstrates that çen refers to (i) public figures such as actors/actresses, sportsmen, musicians, politicians, entrepreneurs, journalists, or academicians $(n=80)$; tv series characters $(n=25)$, 'a hypothetical other' who is not clearly identified by the owner of the tweet $(n=23)$; animals $(n=17)$ and plants $(n=3)$; inanimate objects such as possessions and vehicles $(\mathrm{n}=19)$; organizations such as companies, sports clubs and political parties $(n=15)$; people who are relatives of the owners of the tweets in real life (n=7); places such as cities and countries $(n=3)$ as well as the phenomenon of Covid-19 pandemic ( $n=1)$. As an initial observation, the diversity in the range of the addressees suggests that the phenomenon of baby talk is not limited to simply conveying affection but rather has the potential to display multidimensional pragmatic functions in the construction and maintenance of the interaction in the online sphere.

In order to determine the pragmatic functions performed through baby talk, a more elaborated understanding of the context in which the phenomenon unfolds is needed. As summarized in Table 2 below, the majority of topics which include baby talk belong to the private domain. Twitter users make use of baby talk to (re)produce narratives about their own or their addressee's personal lives such as daily activities, personal and interpersonal emotion-laden experiences, physical characteristics such as appearance, age and health status, salient milestones in life such as graduation, achievements, or becoming a mother/father. Another topic which dominates the baby talk discourse is related to entertainment and media which encompass Twitter users' commentaries on celebrities, television shows and series, sports (particularly

\footnotetext{
${ }^{1} \mathrm{~A}$ form of written laughter which is expressed by typing random letters in Turkish online communication.
} 
football) and news. Additionally, the distribution of topics shows that political issues with regard to the ideologies of political parties and statements of political figures as well as politically affiliated people constitute a prominent topic of interest among Twitter users in sub-corpus. Current state of affairs concerning economics and Covid-19 pandemic are also among the topics the users tweet about by using baby talk.

Table 2. Topics of baby talk in the corpus

\begin{tabular}{l|c}
\hline Topic & No of occurences \\
\hline Private Life & 131 \\
\hline \multicolumn{1}{|c|}{ Daily activities and anectodes } & 42 \\
\hline Physical and biological characteristics & 32 \\
\hline$\quad$ Interpersonal relationships and experience & 33 \\
\hline$\quad$ Moods and feelings & 24 \\
\hline Entertainment \& Media & 106 \\
\hline Sociopolitical & 62 \\
\hline Animals \& Plants & 21 \\
\hline Objects \& Possessions & 19 \\
\hline Other & 8 \\
\hline \multicolumn{2}{r}{ Total } \\
\hline
\end{tabular}

To better assess the pragmatic functions of baby talk across the identified topics, the salient communicative goals of the tweets are also identified. The analysis indicates that baby talk in this sub-corpus is used for showing affection (\%63), conveying sarcasm (\%29), invalidating a political/religious stance or a personal capability/quality (\%11), or expressing criticism or verbal aggression (\%7). Combined with the wide range of topics and the entities denoted by çen in the sub-corpus, the distribution of the communicative goals of the tweets also indicates that the use of baby talk in adult-to-adult communication in online sphere is not limited to simply expressing positive evaluations or conveying affection. It is rather utilized as a discursive strategy to convey non-affective assessments about the referents denoted by çen and thus operationalized frequently in face-work. In this sense, the initial observations suggest that çen acts as a multidirectional face device which enables Twitter users to perform the acts of (i) face-boosting, (ii) imposing face-attacks, and (ii) responding to faceattacks.

\section{Cen as a multidirectional and multifunctional face management device}

\section{Face-boosting}

As indicated previously, çen denotes not only humans but also animals, plants, inanimate beings, places and phenomenon in the sub-corpus. Therefore, a total of 43 tweets which include these addressees were excluded from the second phase of the analysis since the main focus of this section is the functions of çen as a face management device between adults on Twitter. Drawing on Goffmanian concept of face and the model of impoliteness (Culpeper, Impoliteness 20; "Politeness and impoliteness" 391; "Impoliteness and Entertainment" 35; Culpeper et al. 1545) along with the detailed description of 
the context and patterns surrounding çen presented in section 4.1, a total of 304 tweets were analyzed in order to explain how Twitter users make use of baby talk for engaging in face.

In line with the communicative goal of showing affection, the analysis shows that çen is utilized to attend positive face wants in 75 out of 304 tweets in the subcorpus. Within the spectrum of familiarity between the addresser who is the tweet author and the addressee, 19 of these instances unfold in interactions between people who appear to know each other in real life. In such instances, baby talk is used to enhance the face of the other who is either a relative of the tweet author in real life or a friend, lover or colleague. In the contexts where addressee has real-life social connections with the Twitter author, an intensified affectionate tone is adopted to underline the level of intimacy between the Twitter author and the addressee denoted by pronoun çen when baby talk is used to attend to the positive face wants of the addressee, as in excerpt $1^{2}$ below:

(1) (username) çen benim çevgilim misin [BT172] '(username) are you my sweetheart?'

The tweet above is directed at the lover of the tweet author and the baby talk is used as a face-boosting device which highlights the desired qualities of being adorable and cute like a baby. By posing a rhetorical question, the tweet author affirms being lovers and the intimacy between the lovers is discursively maintained.

There are also instances of çen, which are used by Twitter users to address the people they know unilaterally. These addressees constitute mostly actors/actresses, musicians, television characters, football players, and Korean celebrities. In such instances, baby talk indexes the expression of fandom, admiration and love. For example, in excerpt 2 below, a famous Korean boyband member is denoted by çen. The tweet author expresses her sexual attraction to her 'idol' by integrating baby talk into her compliment regarding physical attractiveness.

(2) Hrrrrr bekyunum sekşi mi oldun çen [BT556] '(growling) my Baekhyun, did you get sexy?'

It is interesting to note that diverging from the affect-oriented use of baby talk which is traditionally expected to enhance the infantilizing qualities such as cuteness, smallness and prettiness, baby talk manifested in excerpt above communicates sexual appeal and charm of the addressee. The use of baby talk to enhance positive face of the famous people is frequently observed in fandom talk in which fans of famous people, and particularly fans of Korean celebrities

\footnotetext{
${ }^{2}$ In this paper, the tweets are presented in their original language (Turkish) in the first line followed by their idiomatic translation for English in the second line. Each tweet has a unique ID in the corpus and indicated in brackets. Anonymized proper names and paralinguistic features are indicated in parentheses. Translations provided in this paper were done by the researchers themselves.
} 
compliment their 'idols' for their physical qualities or personal achievements in the sub-corpus.

In the most distant edges of the spectrum of addresser-addressee familiarity level, it is also observed that there are uses of çen $(\mathrm{n}=8)$ for anonymous people whom tweet authors do not know personally such as a person in a photo, a video or an anecdote. In these instances, Twitter users communicate their positive feelings in response to an amiable physical quality or behavior of the addressee, thus in all of those instances baby talk pronoun çen acts as a face-boosting tool.

\section{Imposing face-attack}

At the opposite end of the face work, baby talk is performed by the Twitter users with the particular purpose of attacking or threatening others' faces. In the subcorpus of baby talk, 146 out of 304 tweets were found to communicate face threatening acts (FTAs) manifested through multiple forms of communicative goals. FTAs are directed either to Twitter users in closer circles such as friends, acquaintances, relatives etc., or public Twitter figures such as politicians, celebrities, tv characters, football players/clubs and so on. FTAs appear to perform different communicative goals such as (i) invalidation and criticism (of a political argument, stance or event; of seniority; of professional expertise); (ii) sarcasm and mock-politeness; and (iii) affectionate joking. In some of the tweets, these communicative goals overlap and multiple goals are simultaneously observed. Baby talk instances are predominantly observed to be in the interrogative form (e.g. çen payti mi kuyucakçın? [eng. will you start a new (political) party?] when they function as face threatening acts. This interrogative form conveys rhetorical questions with no expected response and allows the tweet author to question and cancel the validity of an argument.

The first and foremost communicative goal that face threatening baby talk convey is the invalidation of an opinion, stance, statement or a behaviour, mostly observed on the domain of politics, as exemplified in the following excerpts:

(3) Çen bizimi düşünysün çen üzüyme (name) biz Allah a şükür Devletimizin yanındayız. Benim Devletim öyle gereksiz adım atmaz Milletinin her zaman destekçisi ve yanındadır.Bu hastalık döneminde sağlı̆̆ımız için Milletinin elini cebine bile attırmadı.çen rahat uyu (elongated name) [BT20]

'do you care about us, don't you be sad (first name) thank God we stand by our State. My State does not take any unnecessary steps. It is always beside and a supporter of its People. In this epidemic, it did not let its People spent a penny. You can sleep well (elongated first name)'

(4) Çen yine mağdur mu oldun. Vah vah.. :( [BT231] 'Did you become the victim again. How sad.. :('

In the third tweet, the pronoun çen refers to a political figure, the deputy group chair of the main opposition party in Turkey. It has been posted as a response to a tweet by the same politician, criticising the government for rejecting submitted law proposals/bills in the parliamentary voting. The author who is a supporter of the government directs the baby talk pronoun çen multiple times 
to the politician for invalidating his anti-governmental argument and political stance. Baby talking to a famous political figure allows the author to disavow, criticize and ridicule his views on the one hand and to simultaneously mark the author's own political stance on the other hand. In the fourth example, a similar function is observed with a reversed political stance-taking. Second tweet addresses to a politician who is affiliated with the government party. The author of the tweet aims to invalidate a claim of victimhood made by the politician through the use of baby talking. Baby talk frequently occurs to respond to the political figures affiliated with nearly any political ideology. It operates to express disbelief, disapproval, rejection, criticism and ridiculing within the broader frame of invalidation.

Although attacking the face of such powerful social actors by using baby talk would be considered impossible in traditional, face-to-face interactions due to the strict hierarchical boundaries and power, the affordances of the online space lay the ground to observe this unique communicative phenomenon. Moreover, politics is not the only domain to perform face-attacking baby talk with the aim of invalidating one's opinion or stance. It is frequently manifested with respect to age and professional skills or expertise, as illustrated below:

(5) Çen büyüdün de tweet mi atıyon [BT650] 'You grew old and tweet?'

(6) Çen büyüyünce Obradoviç mi olcan aman da aman (BT454) 'Will you become Obradoviç when you grow up' (aman da aman: a Turkish diminutive)

The excerpt 5 is a response to another tweet posted by a young girl talking about her menstruation. The author attacks her face by attempting to invalidate her narrated experience on the basis of the age with the use of baby talk. By rhetorically asking 'you grew old and tweet', the author puts the addressee in a senior/baby-like position and emphasize the young age of the addressee. While a similar expression including baby talk pronoun çen is encountered in the next excerpt (i.e. çen büyüyünce / when you grow up), this time it does not refer to the age of the addressee, but to his professional competency. Addressed to a former professional basketball player and current basketball coach, baby talk attacks the professional face of the interactant by invalidating his skills and expertise.

The second communicative goal of face-threatening baby talk is to express sarcasm and mock-politeness:

(7) Çen çavaşa mı girdin çen [BT21] 'Did you get into a war?'

(8) Çen ne kaday zeki bıdık bir şeysin öyleee oyyy minnoş [BT536] 'What a smart thing you are, oww cutie.'

The seventh excerpt above is posted as a reply to a user who shared an aphorism about having an emotional, spiritual war. The author mocks the use aphorism by directing baby talk to the addressee. Baby talk gives the sarcastic voice to the 
tweet and function to attack the act of tweeting an aphorismic statement, thereby threatening the addressee's face. The next example also involves the conveyance of sarcasm. But it manifested in the form of mock-politeness. As Taylor ("Mock Politeness" 463) puts it, mock politeness occurs when "there is an im/politeness mismatch leading to an implicature of impoliteness." In excerpt 8, the addressee of the tweet gives an indirect answer to a previous question. Excerpt 8 is a reply to this indirect answer as part of a longer interaction. The tweet involves the mismatch created by the presence of both polite and impolite moves in the same utterance (Taylor, "Mock Politeness" 463). Although the adjectives used to describe the addressee are associated with positive qualities such as being smart, it leads to an implicature of impoliteness for the purpose of criticising and mocking the previous utterance. Baby talk, here, helps the author to intensify the mismatch and attack the face of the addressee.

The last communicative goal that baby talking as an FTA involve is to manifest affection and friendly joking. Although, affection was conveyed mostly to boost and enhance others' faces in our corpus, a few of the tweets with the communicative goal of affection are interestingly observed to be threatening others' faces. It is elaborated in the following example:

(9) Utandın mı yoksa çen [BT422]

'Do you feel embarrassed'

(10) Ama çen $52 \mathrm{dk}$ önce kalkmadın kiii msmsmdmd [BT571]

'But you did not get up 52 minutes ago msmsmdmd (random laugh)'

Both of the examples above are posted as responses to a friend's initial tweet and both tweets are later followed by positive and friendly responses by the addressees. In excerpt 9, the author replies to a friend asking why her own cheeks turned red. Suggesting through baby talk that the addressee might be embarrassed of something, the author implicitly threatens the addressee's face. Because, embarrassment might index an unwanted or shameful act. In example 10 , the tweet responds to an initial tweet saying good morning. Since the author knew that the addressee woke up a lot before the time of the tweet, she corrected the addressee through baby talking by saying that he woke up far before his sharing good morning. This example is also considered to be communicating a face-threatening act because the author implied that the addressee lied or gave a false impression to his audience. Both tweets are later replied with a positive evaluation by their addressees. In this case, it might be argued that face-threatening baby talk can occur in affectionate conversations to perform friendly-joking, but might be easily compensated with the ongoing friendly interaction.

\section{Responding to face-attacks}

The analysis shows that another pragmatic function of baby talk is to respond to the face-attacks directed at the addressers themselves or at another person in the relevant context. Theoretically if an interlocutor decides to respond to a faceattack, the options would be to accept or to counter it (Culpeper et al., Pragmatics 
1545). Among 31 instances of baby talk which are identified as responses to face attacks, only two instances are marked as an FTA response of accepting the received impoliteness act. One of these responses is illustrated in excerpt 11 below:

(11) Ben çeni iyi birisi sanmıştım ama çen böyle diyeyek kaybimi kıydın 으 [BT613]

'I thought you were a nice person but you broke my heart with those words'

The excerpt 11 is posted as a reply to the tweet 'even the ugly girls do not write to me anymore' posted by a Twitter user with 42,000 followers. Though there is no referent in that tweet, author of excerpt 11 is a follower who is in digital interaction with this user by following him, liking, retweeting and commenting on his tweets over the course of time. Thus, the author of the tweet takes the statement 'even the ugly girls do not write to me anymore' personally and evaluates it as a face attack imposed on her. As a response, she does not use a counter offensive or defensive strategy, she only accepts the face attack and highlights the fact that she lost face. Accepting the face attack imposes another face damage on the responder, therefore tweet author makes use of baby talk to mitigate the level of damage on her face.

Apart from acceptation of the FTAs, the rest of the responses to face-attacks are observed to be formed as counter strategies. While countering the face-attacks, responders have two distinctive response options, namely defensive and offensive. In counter defensive responses $(\mathrm{n}=11)$, responders prefer to defend their face as in excerpt 12 below illustrates:

(12) Ya çen bana kızabiliy miçin çen bana bana (first name elongated) [BT456]

'You would not get angry with me, would you? Me, your very own (first name)'

In the excerpt above tweet is posted as a response to a thread among friends in which three Twitter users communicate. At one point, one of the users poses an FTA at the author of the tweet by posting 'angry face emoticon' followed by another tweet which states that s/he does not want/accept any explanation (i.e., 'istemez' /'no needed') from the tweet author. The act of refusal imposes another FTA on the author of the tweet and she resorts to using baby talk as a counter defensive strategy to save his/her own face, mitigate the FTA and stop any potential future face-attacks that can be directed by the Twitter user she communicates. By adopting baby talk, author of the tweet communicates the message that she has a very close relationship with that Twitter user, her acts and words are innocent like a baby, and thus she should not be evaluated harshly. The counter strategy works, and the Twitter user responds to the baby talk as follows: 'So you think you can be forgiven like this (referring to use of baby talk)? Well, you were right!'. 
The second type of responses to FTAs through baby talk involves counter offensive strategies $(n=18)$. Excerpt 13 below illustrates such use of baby talk. In this excerpt, the topic is football and the thread starts with a Twitter user (henceforth A for the purposes of ease of explanation) posting an image of an official judiciary document stating a decision regarding a Turkish football club. $\mathrm{A}$ is a fan of that football club and by posting the relevant document, he is celebrating the decision favoring his team as well as downgrading the opposing groups via his use of hashtags. Another Twitter user (henceforth B) responds to this post by siding with the opposing group. Annoyed by the opposition posed, A responds by swearing, to which $B$ responds with baby talk:

(13) Ay kıyamaaaam çok mu sinirlendin çen [BT609] 'Aww poor thing, did you get angry a lot?'

B utilizes baby talk as a response to the derogatory act of swearing which is an FTA directed at him. In contrast to the previous use of defending the face and mitigating the current and future face attacks, this instance of baby talk is intended as a counter offensive strategy to convey the message that the addresser does not take the addressee seriously. By denoting $A$ as çen, author of the tweet implies that B has control and power over A and A should not be treated like an equal or senior but rather a baby. The use of baby talk in this context, then, poses a face threat on $\mathrm{A}$ as he is assessed to be acting childish and immature.

\section{Conclusion}

This study has focused on the interactional phenomenon of baby talk in adultto-adult communication which is recently re-contextualized by the adult Turkish Twitter users in online sphere. Traditionally acknowledged as an affectoriented talk directed at the addressee to express love and intimacy, the analysis of the baby talk instances manifested in our sub-corpus illustrated that the phenomenon in question displays more complicated, multidimensional pragmatic functions in interaction. Çen which is the baby talk variant of the second person singular pronoun you in Turkish is marked as the most distinguishable marker of unfolding baby talk and thus is it employed as a face device by Twitter users to engage in face in diverse ways. Contrary to what one might expect based on the current literature, the majority of tweets (224 out of 304) which utilize baby talk are identified to be performing non-affective functions. Only in 75 of the tweets, baby talk is used in order to appeal to addressee's positive face wants while in the rest the Twitter users either impose face-attacks at others or respond to face-attacks directed at themselves or others in the communication. By empirically reaching this conclusion, we confirm the earlier observational notes regarding the possibilities of baby talk to communicate sarcasm, insult, satire and political wit. We also suggest that new affordances of the online space lead to the transformation of baby talk as a register among adults and its recontextualization as a tool for a new, specific way of online language socialization. 
By exploring online baby talk in adult communication within the framework of face and impoliteness, this study provided insights for a previously unexplored area of research. Further studies are needed and encouraged in order to illustrate a more detailed architecture of this phenomenon by taking into account the different semiotic modes emergent in digitally mediated discourse such as emoticons, memes, GIFs, video clips embedded in online sphere. More importantly, more research is needed to document and explain the emergence of face-to-face baby talk among adults with particular concentration on sociocultural dynamics underlying this phenomenon.

\section{Works Cited}

Balpınar, Zülal. "The Use of Pronouns of Power and Solidarity in Turkish." Dilbilim Araştırmaları, vol. 7, 1996, pp. 288-293. http://dad.boun.edu.tr/tr/pub/issue/ $4533 / 290310$

Bayyurt, Yasemin. The Analysis of the Determining Factors Affecting People's Choice of Address Forms in Turkish. 1992. Lancaster University, Master's Thesis.

Bombar, Meredith L., and Lawrence W. Littig. "Babytalk as a Communication of Intimate Attachment: An Initial Study in Adult Romances and Friendships." Personal Relationships, vol. 3, 1996, pp. 137-158. https://doi.org/10.1111/j.1475-6811.1996.tb00108.x.

Caporael, Linnda R. "The Paralanguage of Caregiving: Baby Talk to the Institutionalized Aged." Journal of Personality and Social Psychology, vol. 40, no. 5, 1981, pp. 876-884. https://doi.org/10.1037/0022-3514.40.5.876.

Caporael, Linnda R., et al. "Secondary Baby Talk: Judgments by Institutionalized Elderly and Their Caregivers." Journal of Personality and Social Psychology, vol. 44, no. 4, 1983, pp. 746-754. https://doi.org/10.1037/0022-3514.44.4.746.

Culpeper, Jonathan. "Towards an Anatomy of Impoliteness." Journal of Pragmatics, vol. 25, no 3, 1996, pp. 349-367. https://doi.org/10.1016/0378-2166(95)00014-3.

Culpeper, Jonathan. "Impoliteness and Entertainment in the Television Quiz Show, The Weakest Link." Journal of Politeness Research, vol 1, no 1, 2005, pp. 35-72. https://doi.org/10.1515/jplr.2005.1.1.35.

Culpeper, Jonathan. Impoliteness: Using Language to Cause Offence. Cambridge University Press, 2011a.

Culpeper, Jonathan. "Politeness and impoliteness." Pragmatics of Society, Volume 5 of Handbooks of Pragmatics, edited by Karin Aijmer and Gisle Andersen, De Gruyter Mouton, 2011b, pp. 391-436. https://doi.org/10.1515/9783110214420.393.

Culpeper, Jonathan, et al. "Impoliteness Revisited: With Special Reference to Dynamic and Prosodic Aspects." Journal of Pragmatics, vol. 35, no. 10-11, 2003, pp. 1545-1579. https://doi.org/10.1016/S0378-2166(02)00118-2.

Goffman, Erving. Interaction Ritual: Essays on Face-to-Face Behaviour. Pantheon Books, 1967.

Ferguson, Charles A. "Baby Talk in Six Languages." American Anthropologist, vol. 66, no 6, 1964, pp. 103-114. https://doi.org/10.1525/aa.1964.66.suppl_3.02a00060.

Ferguson, Charles A. "Baby Talk as a Simplified Register." Talking to Children: Language Input and Acquisition, edited by Catherine A. Snow and Charles A. Ferguson, 1977, pp. 219-236.

Kelkar, Ashok R. "Marathi Baby Talk." Word, vol. 20, no. 1, 1964, pp. 40-54. https://doi.org/10.1080/00437956.1964.11659812. 
Kess, Joseph Francis, and Anita Copeland Kess. "On Nootka Baby Talk." International Journal of American Linguistics, vol. 52, no. 3, 1986, pp. 201-211. https://doi.org/10.1086/466018.

König, Güray. "Türkçe'de Sen/Siz Adıllarının İkinci Tekil Şahıs için Kullanımına Toplumdilbilimsel bir Yaklaşım." IV. Dilbilim Sempozyumu Bildirileri, İstanbul, 1718 May 1990. Edited by A. Sumru Özsoy and Hikmet Sebütekin, 1990, pp. 175184.

Kranjčić, Tamara. Baby Talk in Adult-to-Adult Communication. 2016. Sveučilišta u Zagrebu, Diploma Thesis.

Lüdtke, Ulrike, M., editor. Emotion in Language: Theory, Research, Application. John Benjamins, 2015.

Partington, Alan. "Corpora and Discourse: A Most Congruous Beast." Corpora and Discourse, edited by Alan Partington, et al., Peter Lang, 2004, pp. 11-20.

Partington, Alan. "Evaluating Evaluation and Some Concluding Thoughts on CADS." Corpus-Assisted Discourse Studies on the Iraq Conflict, edited by John Morley and Paul Bayley, Routledge, 2009, pp. 261-304.

Partington, Alan, et al. "Patterns and Meanings in Discourse: Theory and Practice in Corpus-Assisted Discourse Studies." John Benjamins, 2013. https://doi.org/10.1075/scl.55.

Solomon, Olga. "Rethinking Baby Talk." The Handbook of Language Socialization, edited by Alessandro Duranti, et al., Wiley Blackwell, 2011, pp. 121-149. https://doi.org/10.1002/9781444342901.ch5.

Taylor, Charlotte. "Mock Politeness and Culture: Perceptions and Practice in UK and Italian Data." Intercultural Pragmatics, vol. 13, no. 4, 2016, pp. 463-498. https://doi.org/10.1515/ip-2016-0021.

Taylor, Charlotte. "Women are Bitchy but Men are Sarcastic? Investigating Gender and Sarcasm." Gender and Language, vol. 11, no. 3, 2017, pp. 415-445. https://doi.org/10.1558/genl.27906.

Yus, Francisco. "Not All Emoticons are Created Equal." Linguagem Em (Dis)Curso, vol. 14, no. 3, 2014, pp. 511-529. https://doi.org/10.1590/1982-4017-1403040414. 